\title{
Chapter 18 \\ Biological Invasion Policy and Legislation Development and Implementation in South Africa
}

\author{
Peter Lukey iD and Jenny Hall
}

\begin{abstract}
This Chapter describes and reviews the evolving biological invasion policy and legislation development and its implementation in South Africa over approximately the last 160 years. Despite the lack of formal, published government policy on biological invasions, there has been an almost continuous process of law-making over the years, with 50 pieces of being passed since the Xanthium Spinosum Act of 1861. The fundamental legal approach has changed little over this time, with a strong preference for what we have called the 'identify and direct' approach - a 'problem' species is identified and specific people are directed to deal with that species in a specified way. The concept of 'faultless liability' often associated with this approach has been equally resilient (e.g. a landowner is held responsible for clearing invasions on their land even if they were not responsible for introducing the species to the area in the first place). The review also suggests that, from a purely biological invasion management perspective, the South African 'job-provision' policy driver that has dominated biological invasion management activities since the new democratic dispensation in 1994 may have some perverse impacts in the absence of formal biological invasion policy. One of the key conclusions (with the proviso that biological invasions are indeed a significant threat to South African society, the economy, and the environment) is that a comprehensive evidence-based policy-making process should be instituted as a matter of urgency. It is also suggested that climate change concerns and interest in the global Sustainable Development Goals may provide the perfect 'policy-development window' for the development of formal policy on biological invasion in South Africa.
\end{abstract}

P. Lukey $(\triangle)$

Department of Environment, Forestry and Fisheries, Pretoria, South Africa

e-mail: plukey@environment.gov.za

J. Hall

University of Johannesburg, Johannesburg, South Africa

(C) The Author(s) 2020

B. W. van Wilgen et al. (eds.), Biological Invasions in South Africa, Invading

Nature - Springer Series in Invasion Ecology 14,

https://doi.org/10.1007/978-3-030-32394-3_18 


\subsection{Introduction}

This chapter uses an evidence-based policy-making lens to trace biological invasionrelated policy and legislation in South Africa from the mid-1800s to the present. It does this in an attempt to assess how the governance of biological invasions has evolved over time in response to changes in science, politics, fashion, public opinion and sentiment. The chapter begins with an explanation of what is meant by evidencebased policy and legislation. It then moves to an overview of historical developments and trends. In this regard it is noted that the time span covered in the chapter straddles a range of historically important political changes. While it cannot, within the scope of the work, address approaches in African customary law to the management of invasive alien species, it does address the approach under colonialism; unified, but apartheid-driven, South Africa; and the new democratic dispensation. This historical analysis is used to inform some tentative and speculative thoughts about how the policy and legislative regime may, or could, evolve to meet the new and emerging policy drivers.

\subsection{Background to Current Governance, Policy, and Legislation}

Government policy can be defined as a description of the things that government hopes to achieve and the methods and principles it will use to achieve them (Education and Training Unit, n.d.). It therefore defines government's goals and can be used as a basis for decision-making by providing direction on key positions, especially where there are no clear right or wrong answers. As its name implies, policy provides clarity on the political position of government.

Although policy itself is not law, it may often identify the need for legislation to be developed or improved. The resulting legislation will set out the binding and enforceable rules which have been adopted by a law making body-normally, at the national level, Parliament or the Minister in the case of subordinate legislation such as Regulations and Notices. It prescribes what is, or is not, allowed and in the case of things that are conditionally allowed - the standards, procedures and, sometimes, principles that must be followed. If a law is not followed, those responsible for breaking it can incur consequences such as being prosecuted.

If policy sets out the goals and planned activities of government, the law empowers government to put the necessary institutional and legal frameworks in place to achieve the policy goals. Therefore, ideally, law must be guided by current government policy (Education and Training Unit, n.d.).

Currently, the first step in South African government policy-making is the political party conference where political parties discuss, debate and agree their positions and approach to specific issues. The second step is the attempt by the ruling party to make its policy the official government policy. To this end the executive 
branch of government (the President, Deputy-President and Cabinet) develop new policies and laws which the legislative branch (Parliament) may, or may not, approve. This is often a long and slow process of debate and negotiation between the ruling party, opposition parties, the general public, non-government organisations and special interest groups. The process is often informed by discussion documents known as Green Papers and usually culminates in the publication of the policy in the form of a so-called White Paper in the Government Gazette. Although this process is political in nature, it is important to note that policymaking is triggered by current affairs and debates.

In this regard, one of the most important recent developments in policy-making practise is the concept of evidence-based policy-making. According to Marais and Matebesi (2013), the concept has risen to prominence internationally and it emphasises the provision of quality services that are ideologically free, pragmatic, forwardlooking, strategic, responsive, effective, efficient, and scientific.

The South African Government's Department of Planning Monitoring and Evaluation (DPME) in the Presidency is a vocal advocate of evidence-based policymaking and offers courses on the concept to senior government officials as key policy-shapers. DPME believes that evidence-based policy-making helps policymakers and providers of services make better decisions, and achieve better outcomes, by drawing upon the best available evidence from research and evaluation and other sources (DPME and UCT 2014). This includes decisions about the nature, size and dynamics of the problem at hand; policy options that might be considered to address the problem; effective and ineffective interventions to solve the problem; the likely positive and negative consequences of the proposed policy option; the intended and unintended consequences of the proposed policy option; effective and ineffective modes of delivery and implementation; how long the policy will have to run before positive results will be achieved; the resources that will be required to implement the policy; the costs and benefits of the proposed policy, and on whom will these costs and benefits fall; and the sustainability of the policy from an economic, social, and environmental perspective. With this, DPME believes that evidence-based policy-making is about making decisions based on knowing, with an estimated degree of certainty, what will work to achieve which outcomes, for which groups of people, under what conditions, over what time span, and at what costs (DPME and UCT 2014).

According to Strydom et al. (2010) evidence is made up of a range of components-not only scientific - and it is never used in isolation. Scientific evidence typically includes research, surveys, quantitative/statistical data, qualitative data, and the analysis thereof. However, Strydom et al. (2010) note that evidence also includes economic, attitudinal, behavioural and anecdotal evidence; together with knowledge of experts, as well as lay persons, propaganda, judgements, insight/experience, history, analogies, local knowledge and culture.

With this, and despite reservations about how policy-makers often source information with a particular agenda in mind, Strydom et al. (2010) still believe that policies based on evidence are more likely to be better informed, more effective and cost-efficient than policies which are formulated through ordinary time- and 
politically-constrained processes without evidence input. They believe that policy which is based on evidence is also likely to give policy-makers confidence in the decisions that they take and that scientific evidence exposes policy-making to a wider range of validated concepts and experiences, enables policies to be formulated based on solid technical bases and can open up a range of policy options for policymakers to consider.

DPME's evidence-based policy and implementation process recognises four stages: the first is the 'diagnostic' stage that is effectively a problem analysis to define what the actual problem is through cause-and-effect relationships. It also includes identifying the various options for addressing the problem. The second stage is the 'planning' stage which defines the theory of change and describes what must be done to bring about the desired change efficiently and effectively. This is then followed by the 'output' stage where the policy is implemented, monitored, reviewed and refined. The final, fourth stage is an 'outcome and impact' evaluation where the impact of the policy is evaluated (DPME and UCT 2014). Ideally the development of a policy goes through this cycle a few times and is constantly improved and refined.

With this as background, the following sections look at South Africa's biological invasion policies and legislation from the mid-1800s to the present through an evidence-based policy-making lens and attempt to identify what the key policy drivers have been and may be in the future (see supplementary material for a full list of all laws relevant to biological invasions in South Africa since 1861). Although biological invasions involve many groups of species, the following sections deal chiefly with invasive plants as this has been the principal focus historically in formulating biological invasion policy and legislation. The limited mention of other species is therefore a reflection of policy and legislative priorities as opposed to a deliberate omission.

\subsection{The Early Days: 1860 to 1909 -Colonialism and Weeds}

The earliest example of biological invasion legislation in South Africa that we are aware of was passed in 1861. At the time, western-style law-making took place in four politically demarcated areas in South Africa, namely, the British Colony of the Cape of Good Hope; the British Colony of Natal; the Transvaal/South African Republic; and the Orange Free State. (The latter were also briefly British colonies from 1902 to 1910, during which time they were known as the Transvaal and Orange River Colonies).

On 14 August 1861, the Second Parliament of the Colony of the Cape of Good Hope promulgated the Xanthium Spinosum Act (Cape of Good Hope Parliament 1871). This statute was "[a]n Act for promoting the Extirpation of the Burr Weed called Xanthium Spinosum” (Act 22 of 1861, Fig. 18.1). It was specifically aimed at eradicating and destroying "the noxious plant known as the Xanthium Spinosum, or 
Fig. 18.1 The Xanthium Spinosum Act (Act 22 of 1861)

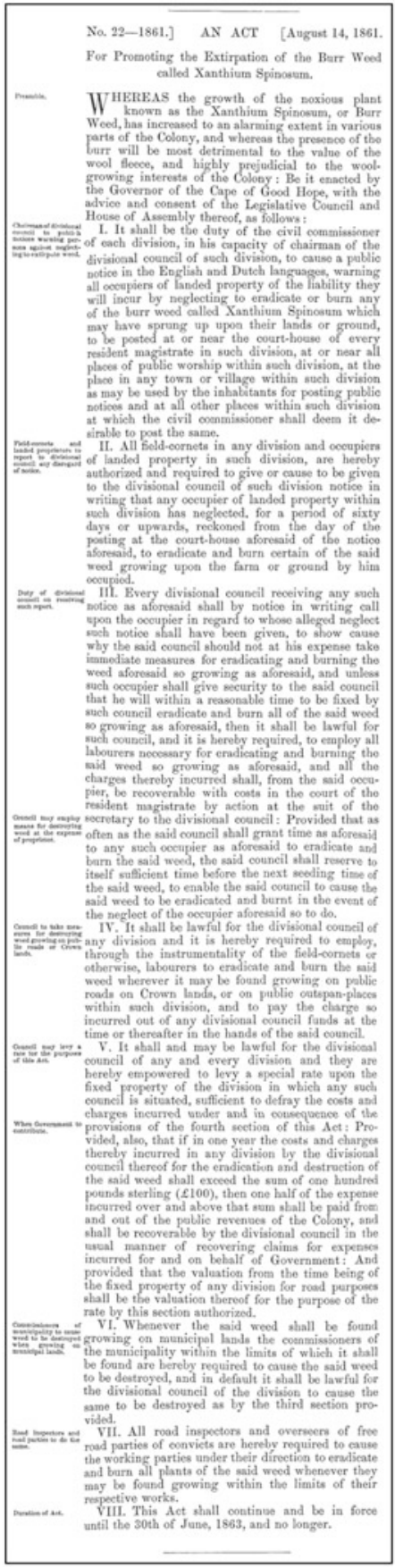




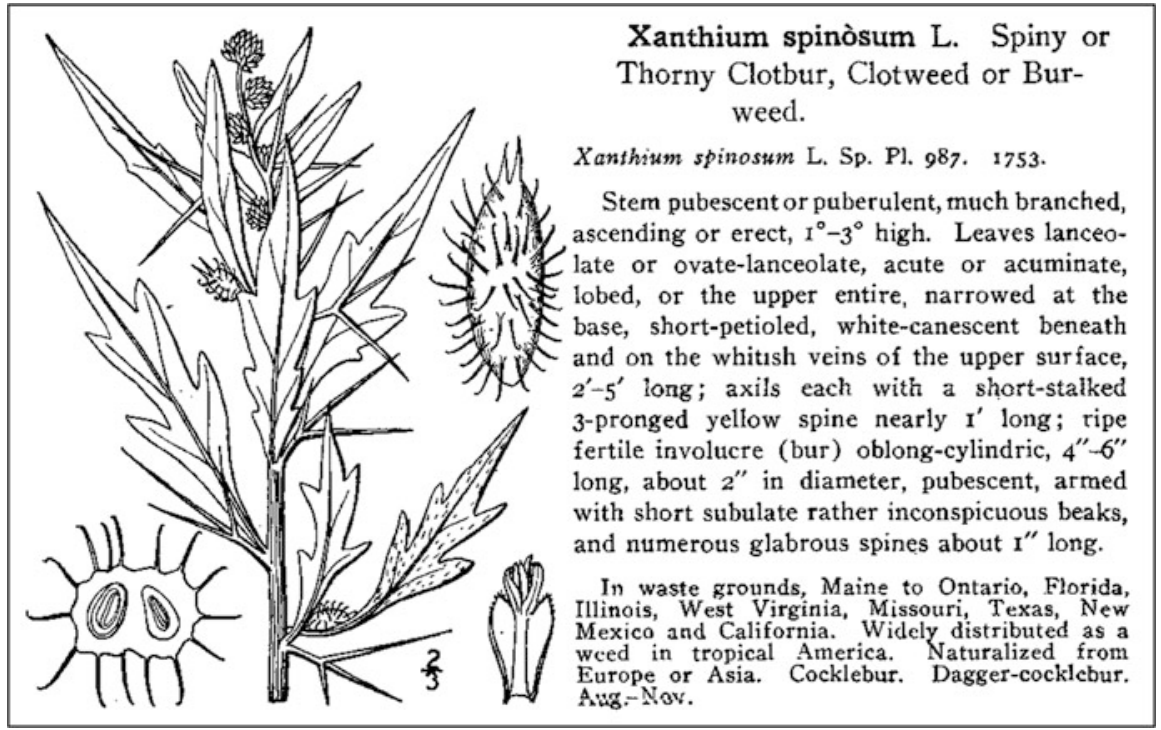

Fig. 18.2 A description of Xanthium spinosum (Cocklebur) from Britton and Brown's 1913 illustrated flora of the Northern United States, Canada and the British possessions (Britton and Brown 1913)

Burr Weed" which had spread "to an alarming extent in various parts of the Colony”. Xanthium spinosum [commonly referred to as Spiny Cocklebur, or (more archaically) Burr Weed] is a South American annual herbaceous plant with many branches which grows up to $1.2 \mathrm{~m}$ high (Fig. 18.2). The fruit of the Spiny Cocklebur is an oval-shaped spiny bur about $10 \mathrm{~mm}$ long, green, with reddish, hooked spines that turn yellowish then brown. It is these burs that triggered the need for Act 22 of 1861 because they were "most detrimental to the value of ...wool fleece, and highly prejudicial to the wool growing interests of the Colony”.

Other than contaminating wool, the Spiny Cocklebur also competes with crop plants and native species along riverbanks and its spiny burs become entwined in the tails, manes and coats of domestic livestock, causing the animals much discomfort (Invasive Species South Africa, n.d.). The seedlings are particularly toxic to domestic livestock and it readily invades overgrazed pastures and spreads at the expense of the native species (Invasive Species South Africa, n.d.). It is also important to note that Spiny Cocklebur is not believed to have any social, economic or environmental benefits. It is clear from the preamble to the Act that wool-growing interests were the principal motivator for the statute.

The Xanthium Spinosum Act made it the duty of civil commissioners to publish notices in or near the court-house of every resident magistrate; near all places of public worship; at places used by the inhabitants for posting public notices and at all other places which the commissioner deemed desirable, "warning all occupiers of landed property of the liability they will incur by neglecting to eradicate or burn any 
of the burr weed called Xanthium Spinosum which may have sprung up upon their lands or ground".

The occupiers of landed property were then given 60 days to comply before all field-cornets-civilian officials invested with the rank and responsibilities of a military officer and with judicial powers enabling them to act as a local administrator and magistrate-and other occupiers were required to report all cases of non-compliance to the Divisional Council. The Council, taking seeding cycles into account, had to then allow the occupier a reasonable chance to eradicate or burn the weed on their property, failing which the Council would do the job and claim the cost from the occupier-the so-called 'step in and pay the bill' principle. The same applied to errant municipalities where the weed was found growing on municipal land.

The law was not limited to private occupiers. It also required Council funds to be used to employ "labourers to eradicate and burn the said weed wherever it may be found growing on public roads on Crown lands, or on public outspan-places". Private landowners were indirectly responsible for part of these costs too because Council was allowed to raise these funds through property rates, although it could get half of the funds from "the public revenues of the Colony" if the eradication costs "exceeded one hundred pounds sterling (£100)". Moreover, "all road inspectors and overseers of free road parties of convicts" were required to ensure that "the working parties under their direction" eradicated and burned all Burr Weed plants "whenever they may be found growing within the limits of their respective works".

As if it were an experiment, the Act was only in force "until the 30th of June, 1863, and no longer" (own emphasis).

The basic structure of the Xanthium Spinosum Act, 1861 (Fig. 18.1) has remained remarkably resilient as an approach for biological invasion governance. First, it identifies the specific problem species. Secondly, it places a duty of care on private land-owners to eradicate the species on their land. Thirdly, it requires municipalities and other government custodians of state-owned land to eradicate the species on their land. The logic of this 'identify and direct' approach appears to be that if everyone who is directed to comply complies, then the identified problem will be completely solved. It may also be suggested that the Act was remarkably progressive in its funding model. However, if one accepts few, if any, people who were required to eradicate the weed were actually responsible for the weed's occurrence, it could also be seen as holding the 'victims' of the weed accountable for its control. This 'faultless liability' is an approach usually used with great circumspection in law because of the tension that it creates with the notion of fairness. It therefore suggests that the issue of managing the invasive species was considered to be sufficiently serious to merit the use of extreme regulatory measures.

It is noted, however, that the approach in the Act is entirely reactive as, although the Act regulates the impact of a particular problem species, it does not prevent the introduction or use of other alien species that may become problematic. In this regard, Bennett and van Sittert (2018) [citing Crosby (1986) and van Sittert (2000)] note that it was the farmers' purposeful introduction of alien agricultural plants, such 
as wheat, that led to the accidental introduction of Xanthium spinosum in South Africa in the first place.

The Xanthium Spinosum Act became the basis for biological invasion governance for years to come. It was extended through Act 27 of 1864 of the Cape of Good Hope and appears to have been largely replicated in the statutes of the Colony of Natal, specifically Law 20, 1861. The latter was repealed and re-enacted with amendments 13 years later by Law 38 of 1874 the purpose of which was "To prevent the spread of the growth of the Xanthium Spinosum Burr Weed". In this 1874 amendment, there is an admission that "the growth of the noxious plant known as the Xanthium Spinosum Burr Weed has increased to an alarming extent in various parts of the Colony, and is prejudicial to the farming interests of the Colony". Importantly, there is also the admission in the preamble that "the Law hitherto in force has failed to check the spread thereof, and it has been necessary to make other and more stringent regulations to effect its extermination". Despite these admissions, it was more the penalties that changed than the approach. In this regard, the more stringent regulations included occupiers of private land being liable to a recurring "penalty for leaving Burr Weed upon their lands". This penalty was no doubt why Burr Weed became known as Boetebos (a Dutch and Afrikaans term which can be literally translated as 'penalty bush'). In cases of non-compliance where the authority stepped in and claimed the bill the "expense thus incurred [was] chargeable upon the land with 6 per cent interest". The Transvaal Republic appears to have promulgated a similar law in 1872-the Xanthium Spinosum Law (Law 1 of 1872).

Up until this time, the emphasis had been overwhelmingly on weeds. However, 14 years later, the Government of the Transvaal Republic set the scene for the use of the 'identify and direct' approach to deal with a faunal species i.e. the Australian Bug (the Cottony Cushion Scale-Icerya purchasi) and other problem insects, when the Volksraad made the Australian Bug Resolution of 24 July 1888. The Resolution authorised the Executive Council to make Regulations and provisions in respect of the Australian Bug or other noxious insects. These Regulations and provisions included: the chopping down and destruction by the owner of trees and plants infected by the Australian Bug or other noxious insects; the power of the government to do the chopping or destroying at the cost of the owner and without any entitlement by the owner to claim compensation, if the owner is negligent; and the power to make additional Regulations. As Icerya purchasi is a pest to citrus crops, it is highly likely that it was influential citrus farmers who lobbied for this Resolution.

The focus, however, remained on weeds and by 1889, the Government of the Cape of Good Hope had expanded and mainstreamed their weed legislation into the Divisional Councils Act (Act 40 of 1889), Sub-Division VI, Part I, Extirpation of Xanthium Spinosum and other Noxious Weeds and Plants. These weed provisions, although similar to Act 22 of 1861, also included additional clauses such as allowing for the special exemption of river beds; the power to identify other "noxious weeds and plants" to be treated as if they were Xanthium spinosum, and the employment of weed inspectors with the power to access all land. Given that the Spiny Cocklebur competes with crop plants and native species along riverbanks, it is not clear why the 
Governor on the request of the Council should exempt identified beds of public rivers from the requirement that every owner and every occupier of land must eradicate or destroy the weed.

Treating other noxious weeds and plants as if they were Xanthium spinosum-a weed with no benefits to the South African economy, society or environmentmarks an interesting 'one-size-fits-all' policy development that, history has shown, appears to be at the root of much of the more recent public or special interest pushback against biological invasion legislation and its implementation (see the trout issue in Weyl et al. 2020, Chap. 6, as well as the controversy around the Himalayan Tahr in Sect. 18.7.4 below).

The Transvaal Republic made further advances in its regulation of weeds in 1897 with its Eradication of Burweed Law (Law 4 of 1897) which dealt with "the control of certain weeds-the Xanthium Spinosum and the Scotch Thistle-which are increasing very considerably in various parts of the South African Republic, and which render the wool valueless where they grow". Although the Cape's Divisional Councils Act (Act 40 of 1889) described above opened the door for the regulation of weeds other than Xanthium spinosum, this 1897 law appears to mark the start of the 'listing' of species. In this regard, despite Scotch Thistle (Onopordum acanthium) being a plant which can form dense, impenetrable stands that compete with field crops and forage plants, the protection of wool farmers still appears to be the overriding motivation for this law. As with the Cape legislation, Law 4 of 1897 makes it "the duty of all burghers (citizens) to eradicate the [weeds] on their properties". Like the Natal Law, there is also a provision for penalties for non-compliance, which are equally applicable to "officials charged with the supervision of Government grounds", where, if a person is "negligent in respect of" the duty to eradicate the weeds they "shall be liable to a fine not exceeding $£ 1$, or, in case of non-payment thereof, to imprisonment with or without hard labour for a period not exceeding three days for the first offence, or for a second offence to a fine not exceeding $£ 5$, or in case of non-payment thereof to imprisonment for a period not exceeding 14 days with or without hard labour, and for each successive offence to a fine not exceeding $£ 20$ in addition to imprisonment for a period not exceeding six weeks with or without hard labour". Interestingly, in what appears to be an attempt to promote compliance through improved detection of non-compliance, the Transvaal Law noted that "the Government may grant a part, but not more than a third of the fines which have been imposed, to the informant."

In 1901, Natal identified another Xanthium species for control through their Xanthium Strumarium Burr Weed Act (Act 20 of 1901) which required that "the Xanthium Spinosum Law No. 38, 1874, shall apply as fully and effectually to the Xanthium Strumarium Burr Weed as though such weed had been originally included in the said Law".

In the 3 years before the four colonies became a union in 1910, there appears to have been a flurry of 'noxious weed' law-making. The Cape Colony started with its Divisional Councils Act Amendment Act (Act 17 of 1907) when the Act conferred "upon Divisional Councils greater or additional powers for the eradication or extirpation of noxious weeds or plants, and in that respect to amend the 
Divisional Council Act, 1889". Once again, many of the basic 'identify and direct' provisions of Act 22 of 1861 remained visible and although Xanthium Spinosum was specifically mentioned, it also allowed for further plants to be identified and controlled. Importantly, the Act also included a "penalty for neglect" where "upon proof of his neglect such owner or occupier shall be deemed to be guilty of an offence under this Act, and shall upon conviction be subject to a fine not exceeding twenty pounds and such owner or occupier shall be liable to the same penalty for every week or part of a week during which he shall fail, after his first conviction, to comply..." Another interesting addition that appears to counter the strange 1889 'river bed exemption' is the provision that "in the eradication of noxious weeds it shall be an offence to place such weeds in any river or any defined water course. Any person contravening this section shall upon conviction be liable to a penalty not exceeding twenty pounds." By identifying a specific dispersal pathway, namely rivers and water courses, this provision may also represent a broadening of the approach to invasive species management. The Act was followed up with The Rural Council (Cape Division) Act (Act 33 of 1909) which empowered Rural Councils to "make, alter, revoke or amend regulations ...for the more effectual eradication or destruction or prevention of the spread from adjoining divisions of Xanthium Spinosum or any other noxious weed or plant."

The Transvaal followed in 1909 with their Noxious Weeds Act (Act 12 of 1909) to "make better provision for the Eradication of Noxious Weeds". Act 12 of 1909 empowered the Governor to make regulations: a) imposing a duty on the occupier or owners of land, mining title holders and holders of grazing rights on Crown Land to clear and keep clear their land of noxious weeds; b) prescribing the manner in which noxious weeds had to be eradicated in respect of this duty; c) empowering any official of the Department of Agriculture, field cornets, or police officers to inspect land and issue directions by written notice to clear that land of any noxious weed; $d$ ) empowering these officials to eradicate weeds in cases of non-compliance; e) providing for the recovery of the cost of eradication of noxious weeds from the person who is in default and the mode of such recovery; f) preventing the introduction into the Colony or the sale of any plant, seed or grain, which is likely to propagate or spread the growth of noxious weeds; and g) for generally preventing the spread of noxious weeds in the Colony. Penalties for non-compliance were also updated-"Penalties may be imposed for a breach of or failure to comply with any such regulation not exceeding a fine of fifty pounds or in default of payment imprisonment with or without hard labour for a period of six months." In addition to the provision relating to eradication method prescription, the acknowledgement of the role of 'prevention' - restricting import or sale-is an important regulatory development. As with the Cape Colony's Divisional Councils Act Amendment Act (Act 17 of 1907) regulation of a specific dispersal pathway, the regulation of introduction pathways, namely import and sale, by Transvaal's Noxious Weeds Act (Act 12 of 1909) represents a further broadening of the approach to invasive species management. Furthermore, given the traditional and ongoing tension between mining and agriculture which was driven by competing land use, the specific mention of 'mining title holders' in an Act that clearly protects farming interests may also be a 
significant policy development. However, this was only a framework Act which could have no real impact until Regulations were published. As an acknowledgement of this fact, the new law made it clear that Law 4 of 1897 was only repealed from the date of the publication of any Regulations in terms of the Act. The Orange River Colony also published their own Noxious Weeds Act (Act 23 of 1909).

In summary, during the 50 year period $1860-1909$, policy and legislation focused on a limited number of (mostly plant) species. In addition, the primary driver in policy and legislation dealing with biological invasions was to protect the interests of farmers by placing a general 'duty of care' on all landowners and land users to eradicate identified plants. The underlying policy consideration was therefore the protection of a specific economic sector by making everyone responsible for managing the problem - often in a faultless liability manner. Acknowledged failures of the policy and legislation in meeting stated objectives were on the whole met with increasingly stringent penalties for non-compliance rather than a shift in the underlying approach. As will be seen, the identification of species and direction of response-the 'identify and direct' approach — continues to remain a core component of biological invasion legislation, if not policy, today.

\subsection{Dealing with Union: 1910 to $1934-$ Regulatory Hiatus}

The Union of South Africa came into being on 31 May 1910 with the unification of the four British colonies of the Cape, Natal, Transvaal (formerly the Boer South African Republic) and Orange River (formerly the Boer republic of the Orange Free State). These former colonies became the Union's provinces known as the Cape, Natal, Transvaal and Orange Free State provinces respectively. At its establishment, the Union of South Africa was a self-governing autonomous dominion of the British Empire until independence from Britain through the 1926 Balfour Declaration and the 1931 Statute of Westminster. The Union became the Republic of South Africa on 31 May 1961 with the enactment of a new constitution.

On the biological invasion front, there appears to have been a regulatory hiatus following union in 1910. Apart from the new Transvaal Province's 1912 Ordinance- "An Ordinance to Consolidate and Amend the Law relating to Municipal Government in this Province and the establishment of Health Committees therein, and to provide for matters incidental thereto" (Ord. No. 9 of 1912)—which empowered Councils to make weed-related by-laws, the first 24 years following union was relatively quiet on the weed front. However, in addition to the usual suspect, Xanthium spinosum, Ord. 9 of 1912 also specifically identified Cannabis indica (Marijuana) and Tagetes minuta (Khakibos) as noxious weeds. This is significant because, unlike Xanthium spinosum, these plants provide benefits to some people-Marijuana for its narcotic and associated cultural uses, and, as hemp, for its use as a textile, for paper and as rope; and Khakibos for its essential oil (currently grown commercially in South Africa, France and North America for the same purpose). Furthermore, this could be the first time that weed regulations 
were being considered for use in addressing a problem that was not specifically related to the plant's impact on agriculture. For example, although the politics and economics of the early Marijuana industry is beyond the scope of this Chapter, it is probably safe to say that Cannabis indica was considered to be far more of a social problem than an agricultural economy problem.

According to Bennett and van Sittert (2018), from 1910 to 1913, the Union delegated weed control to the provinces through the Financial Relations Act (Act 10 of 1913). Bennett and van Sittert (2018) also note that from 1913 to 1937 provincial administrators were made responsible for controlling weeds through Part 5 of the Union of South Africa Act of 1909. Although each province still used their colonial laws to regulate weed control, Bennett and van Sittert (2018) describe an attempt in 1916 by the South African Farmers Union to get the Minister of Agriculture to rationalise and harmonise these provincial laws and the Provincial Administration Commission's failed suggestion that the Cape's system be applied nationally.

During this quiet period the Orange Free State amended its Noxious Weeds Act (Act 23 of 1909) with its 1920 Noxious Weeds Amendment Ordinance (Ordinance 6 of 1920); principally to replace the word 'Governor' with 'Administrator'. However, an interesting new provision was also slipped into this 'editorial' amendment that empowered the administrator to make grants, or to grant other assistance, monetary or otherwise, for "the effectual eradication of noxious weeds".

Further legislation, like Transvaal's 1928 Local Government (Noxious Weeds) Amendment (Ordinance 8 of 1928), concentrated largely on administrative amendments with few significant changes in policy or approach.

Apart from starting to include contested species-species that were considered problematic by some, but beneficial by others-and the potential government funding of eradication programmes, this period also appears to have introduced very few changes in policy or legislative approach. Notwithstanding this, it is possible that this period may have seen the introduction of a new policy-driver that was distinctly South African, namely, nationalism.

In this regard, the closing years of the nineteenth century saw botanists beginning to advocate for the recognition and protection of the Western Cape's unique native fynbos flora which was under threat from extensive transformations of the landscape due to farming, forestry, urban sprawl and wild flower-picking (Pooley 2010). Although this lobby was ignored by a largely indifferent public, Pooley (2010) believes that this may have changed in the context of post-South African war efforts to build unity among the English and Afrikaner populations, and where invasive alien plants presented a physical and symbolic opportunity for the botanist's advocacy. Indeed, Pooley proposes that the then new discipline of ecology suggested metaphors of integration (and segregation) that both politicians and natural scientists "could exploit to their mutual benefit" (Pooley 2010).

Pooley (2010) believes that botany, patriotism and the politics of national unity were closely bound up and that "floral nativism... provided both a sense of identity for an emerging White settler nationalism and a justification for evicting the underclass from the commons" (Pooley 2010, citing van Sittert 2003). 
Bennett (2014) notes that there is a developed literature focusing on how fears of invasive alien plants also expressed South African nationalism in its apartheid and post-apartheid forms. In this regard there is a suggestion that a discourse around the 'danger' of invasive alien species in South Africa gained momentum in the late 1950s and early 1960s (Bennett 2014, citing Carruthers 2011) and that "nationalism... provided justification for eradicating these ...species". Bennett (2014) notes that Peretti (2010) takes this argument further by linking South African interest in biological invasions in the 1980s with ideologies of apartheid that were "concerned with separating the pure from impure" (see also van Wilgen 2020, Sect. 2.14).

\subsection{Intentionally Introduced Invasive Species 1860-1935 (Post Union But Pre-independence)}

\subsubsection{Alien Trees as a Solution to Problems}

With reference to the most recent review of biological invasions, included in the 25 invasive species with 'severe impact', van Wilgen and Wilson's status report (2018) identifies 1 freshwater fish (4\%), 4 freshwater invertebrates (16\%), 17 terrestrial and freshwater plants $(68 \%)$ and 3 terrestrial invertebrates $(12 \%)$. Although the fact that plants make up the majority of species with severe impacts appears to align with the historical weed focus which was followed up until 1934, what does not align is the fact that included in the 17 terrestrial and freshwater plants are 11 tree species (44\% of total species with severe impact). The reason for this is simply that before 1935 the policy was that trees, especially invasive trees, were regarded as being a solution rather than a problem.

According to Kruger and Bennett (2013, citing Barton 2002, Beinart 2003, Grove 1989, and Bennett 2010), the second half of the nineteenth century saw a number of forestry enthusiasts in Southern Africa propagating the idea that tree-planting would increase the amount of rain in dry areas and would improve streamflow. These claims motivated white settlers in all four colonies to deliberately introduce alien trees and to engage in tree-planting efforts to increase rainfall and soil fertility, slow erosion, stop desertification and relieve or cure tropical diseases, such as malaria (Kruger and Bennett 2013, citing Bennett 2010). Despite reservations based on observations to the contrary, the belief that alien forests stopped erosion and conserved water became and remained the official South African forest management policy until the mid-1930s (Kruger and Bennett 2013, citing Beinart 2003). This policy was reinforced by the findings of the Union-wide 1923 Drought Investigation Commission which supported the idea that forests had a positive climatic and hydrological influence (Kruger and Bennett 2013 citing Beinart 2003).

However, by the early 1930s this dogma was being formally challenged. For example, in 1932 the Department of Forestry directly contradicted the belief that 
trees improve streamflow when it adopted a policy of keeping a 20-m buffer zone between a stream and a plantation with the aim of mitigating the effects of their plantations on streamflow (Kruger and Bennett 2013, citing Malherbe 1968). According to Kruger and Bennett (2013), public and scientific criticism of afforestation-mainly that it decreased streamflow in higher rainfall zones-reached a crescendo prior to what they refer to as a seminal year in the history of South African forest hydrology research-1935, when South Africa hosted the Fourth Empire Forestry Conference which "brought together foresters from around the British Empire to discuss current findings, to talk about problems and to coordinate empire-wide policies."

Kruger and Bennett (2013) believed that the 1935 Empire Forestry Conference crystallised political support for the emerging major, long-term research programme that would, among others, scientifically debunk the afforestation myths. Furthermore, in an early demand for evidence-based policy-making, the Conference provided a platform for politicians and critics of forestry to call for policies that were evidence-based, practical and under constant review. With regards to evidence, foresters agreed that in balancing theory and experience, experience should trump theory until the theory was proved in practice - an unusual step at a time when scientific theory generally enjoyed priority.

With reference to the concept of 'faultless liability' discussed above, it is important to note that in the 1880 s and 1890 s, in support of the 'forestry has a positive climatic and hydrological influence' policy, the Cape Colony's newly-founded Department of Agriculture distributed seeds and plants freely or at little cost (Kruger and Bennett 2013). Furthermore, from an invasive species management policy and legislation perspective, unlike accidentally-introduced weeds like Xanthium spinosum, many trees are examples of species which were intentionally introduced with very different pathways of entry. Consequently one would expect different regulatory approaches to the management of accidently and intentionally introduced invasive species. However, as discussed in Sect. 18.8.2 below, this is not necessarily the case.

\subsubsection{The Jointed Cactus and Weeds Acts}

The promulgation of the Jointed Cactus Eradication Act (Act 52 of 1934) marked a subtle change in the legislative approach. Although the Act was still largely based on the 'identify and direct' approach, it also contained a provision that was sensitive to the issue of 'faultless liability'. Other than simply putting the burden of eradication on the occupier or owner of land, section 3 of the Act provides for the eradication of Opuntia aurantiaca on private land by a designated official who is allowed to “...take with him upon such land the labour, animals, vehicles, instruments, appliances, drugs or any other thing which in his opinion is necessary or required for the purpose of eradicating such cactus." After this initial clearing at no cost to the occupier or land owner, a clearance certificate was issued (section 7) together with a 
continuance order requiring the occupier or landowner to keep the land clear (section 8). Even when applying the traditional identify and direct approach, the Act therefore also provided for government assistance to the occupier and landowner through, what could be regarded as, an early form of our South Africa's current public works programmes.

Another important development was the inclusion of information and reporting provisions in terms of which government had to be informed of the presence of jointed cactus (section 1) and could collect such information (section 2) as it required.

These two important developments allowed for a more strategic approach to eradication based on reported or observed infestation data which could be used to inform government co-ordinated eradication campaigns. According to Bennett and van Sittert (2018), jointed cactus had become the most serious weed in the country by the 1920s, and government's response to the jointed cactus infestation in the Eastern Cape following the promulgation of the Jointed Cactus Eradication Act proved to be the one exception to the general rule of weak state enforcement of weed legislation. Using the powers provided under the Act, officials took a strong interventionist approach using teams of labourers to mechanically clear private farms. The Department of Agriculture then implemented a program of biological control using imported cochineal beetles and the moth Cactoblastis cactorum (Bennett and van Sittert 2018).

Three years after the Jointed Cactus Eradication Act (Act 52 of 1934), the Weeds Act (Act 42 of 1937) was promulgated. This Act repealed and replaced all of the existing colonial and post-colonial weeds legislation. Although the Weeds Act was largely modelled on the Jointed Cactus Eradication Act, it appears to have de-emphasised and diluted provisions for state-sponsored interventions on private land, effectively returning to a reliance on the concept of 'faultless liability'.

\subsection{An Expanding Agenda (1935-1993)}

The Weeds Act (Act 42 of 1937) remained the principal biological invasion legislation until it was replaced by the Conservation of Agricultural Resources Act (Act 43 of 1983) (CARA) some 46 years later. From the 1970s onwards, legislation started reflecting an expanding agenda. As discussed previously, until this time the main policy driver for passing legislation to manage invasive species was economic and specifically the economic interests of the agricultural sector. In other words, if invasive species were identified as having a negative impact on an economic sector or activity they needed to be controlled. Although this approach continued into the next phase of legislation, as is illustrated by the example of CARA (see Sect. 18.6.2 below), changes were afoot. 


\subsubsection{Expanding the Policy Drivers to Include Water and the Environment (1970-)}

According to Kruger and Bennett (2013), the first scientific policy analysis regarding water and forests in South Africa, published in 1949, used scientific evidence and theoretical principles to challenge the myths of the hydrological benefits of forests, clarify policy options and introduce the concept that catchment management should be part of a broader system of ecosystem management. Subsequent reports of interdepartmental committees on the conservation of mountain catchments (1961) and afforestation and water supplies (1968) and those of a Commission of Inquiry into Water Matters (1970) provided the evidence that informed South African forestry and water policies for the next 30 years (Kruger and Bennett 2013).

The promulgation of the Mountain Catchment Areas Act (Act 63 of 1970) arguably signalled the first attempt at expanding economic policy drivers regarding biological invasion management to include environmental ones. Given the research and review processes described above, this Act was clearly a product of 'evidencebased policy-making'.

The Mountain Catchment Areas Act is primarily environmental in nature, as its purpose is to provide for the conservation, use, management and control of land situated in declared mountain catchment areas. Further evidence for the idea that the Act is underpinned by environmental concerns is that catchments which are declared in terms of the Act are now recognised as protected areas in terms of section 9 of the National Environmental Management: Protected Areas Act (Act 57 of 2003). It also has an underlying purpose of conserving water resources through the conservation of soil and vegetation. Section 3 of the Act empowers the Minister to issue directions, which may be applicable to catchment areas as well as areas within $5 \mathrm{~km}$ of a catchment area, relating to "the destruction of vegetation which is, in the opinion of the Minister, intruding vegetation”.

However, although these provisions represent a broadening in existing policy approaches, the power does not seem to have been utilised in practice. Furthermore, these environmental concerns did not extend to other protected areas such as national parks in any meaningful way. For example, the National Parks Act (Act 57 of 1976) focuses very much on protecting resources in the parks from immediate physical human activities such as hunting and picking plants (cf, for example, section 21). A possible exception to this in respect of alien animals is the provision in section 21 (g) which says that no person may "introduce any animal or permit any domestic animal to stray into or enter a park”.

\subsubsection{CARA and the Return to Form (1983-)}

Notwithstanding the broadening of policy drivers introduced by the Mountain Catchment Areas Act, the 1980s largely returned to form from a regulatory approach 
perspective, when the Conservation of Agricultural Resources Act (Act 43 of 1983) (CARA) was promulgated. CARA introduced a range of regulatory mechanisms that are aimed at protecting resources which the agricultural sector relies on. One of these is the power of the Minister to declare any plant to be a weed or invader plant, either nationwide or in specific areas only (section 2(3)). Unlike other provisions in the Act which expressly do not apply in urban areas, a more progressive approach is taken to weeds and invader plants in section 2(2) which provides that the "provisions of this Act relating to weeds and invader plants shall also apply to land which is situated within an urban area”. From a policy perspective, this was an interesting development because it extends the reach of regulatory control to prevent the spread of all the listed species, irrespective of where they are found.

The first set of Regulations aimed at giving effect to the weed and invader plant provisions in the Act were passed in 1984 (GNR 1048 GG 9238, 25 May 1984). These Regulations included a list of approximately 50 species which were categorised as being either 'weeds' or 'invader plants'. Regulations 15 and 16, which concern problem plants, were amended in March 2001. In this last 'problem plant' amendment to the CARA Regulations, the list of plants was expanded to include many more species (198) and it also categorised them as falling within one of three categories (GNR 280 GG 22166, 30 March 2001). The categorisation of the species shows the underlying policy issues which government has to wrestle with. Whilst category 1 plants were to be very tightly controlled and no person would be allowed to sell, advertise, exhibit, exchange or dispose of them, categories 2 and 3 showed some more flexibility because of the utility or value of the species. In this regard, category 2 species are known to be problematic, but because of their commercial value or other uses they are allowed in demarcated sites. Category 3 species include ornamental plants that can be kept, but not propagated.

Interestingly, with regards to category 2 species, a statement made by the then Minister of Agriculture and Land Affairs, Thoko Didiza, reflected the tension between wanting to exploit, or wanting to destroy invasive alien species when she said "The government is fully supportive of the commercial ventures based on these species, recognizing as it does the important contribution that they make to the South African economy and the welfare of its people. ... However, this welfare is under threat from the significant impacts of alien invasive plants, and we must face up to, and deal with this problem" (Hanks 2001).

\subsubsection{Moving Beyond Plants (1983-)}

Another way in which the underlying policy approach was expanded was a new or increased focus on regulating animals, marine species, and other organisms which cause disease. In this regard, the Agricultural Pests Act (Act 36 of 1983) and the Animal Diseases Act (Act 35 of 1984) both provided for the control of the importation of 'exotic animals' or parasites and diseases. Regulations passed in 1998 in terms of the Marine Living Resources Act (Act 18 of 1998)—which has the 
conservation of the marine ecosystem as one of its express objectives-require applications for mariculture activities to contain information regarding how the introduction of alien commensals, parasites and pathogens will be avoided and what measures will be taken to avoid the establishment of alien species in the wild (Regulation 61 of GNR 111 GG 19205, 2 September 1998). In 2013, a proposed amendment to the Act was published which allowed for more direct control over the release of alien species through a new section 43A (GN 434 GG 36413, 25 April 2013). The Bill, however, has not been passed to date.

\subsubsection{1: Rethinking Policy}

Apart from these legislative developments in the late 1980s and early 1990s, the apartheid government of the day was also reassessing its environmental policy. One of the major initiatives during this period was the President's Council's investigations and recommendations on environmental policy. The mandate of the Council included 'a particular reference to the ecological, economic, social and legal implications thereof'. In 1991 the President's Council released its report (The President's Council 1991) which made proposals for a national environmental management policy.

Amongst the many issues that the Council considered, it is clear that it was alive to the issue of invasive alien species; it contained just over a page dedicated to the issue, as well as references in other areas of the report. Although some of the Council's proposals appeared quite proactive, others seemed somewhat resigned, pragmatic and/or highly subjective. For example, it made comments such as "trees improve any landscape". In a seemingly progressive stance, and as seen from the extract below, the Council appeared willing to expand the traditional approach of managing invasive alien species for purely economic reasons by also including environmental considerations: "In addition to the threat to agriculture, the rapid spread of invasive alien plants such as the jointed cactus, Australian acacias, hakea, lantana and many others are also a threat to the native flora and fauna and to natural habitats. Alien vegetation affects the productivity of river systems and wetlands. The banks of many of our rivers, particularly the upper reaches, are completely overgrown with Australian acacias (wattles). From here they spread up the mountain slopes. The open water of many rivers, dams and vleis is being choked by one or more of South American weeds e.g. the water hyacinth, and the water fern (Salvinia). Little has been done to control these invasive plants, because they affect only the natural productivity of the waters and their recreational potential, which as yet do not enjoy a high priority rating." (The President's Council 1991).

As a policy suggestion, the Council's opinion was that the strategy to address these negative impacts should be to "clear sparsely infested areas" and to "contain the dense stands to prevent them from spreading until more effective control measures have been developed." The report also signals the need for a pragmatic approach. For example, it sounds a warning to 'purists' that ". . . a fact that must be 
accepted by conservationists is that not all alien plants are undesirable. Many varieties of trees introduced over the past 300 years have been a decided asset and present no threat to our indigenous fauna or flora". This remark is coupled with another that reveals some insight to the prevailing sentimentality for certain alien species "Trees improve any landscape and play a vital role in urban areas. They soften the sharp edges of our cities and attract birds and other wildlife, bringing nature into the heart of the city.... Collectively, the gardens of suburban areas will play an increasingly important role in future in the total conservation effort, as natural habitat dwindles. While at best suburban gardens and parks are an artificial habitat, they can contribute to ensuring the survival of many species which might otherwise disappear as natural habitat is destroyed."

This sentimentality towards trees reveals a dualistic approach to the management of alien species that persists today. On the one hand nationalist policies stimulate a form of xenophobia towards all alien species. On the other hand, and in parallel, there is a distinct nostalgia and cultural attachment to certain species. This may explain why, for example, several of the trees that are still protected in terms of section 12 of the National Forests Act (Act 84 of 1998) are alien trees. These include the Araucaria heterophylla-Norfolk Island Pine-planted in 1826 by the wife of the last Landdrost (magistrate) of Stellenbosch and a range of other trees associated with historical milestones.

Under the report's discussion on the conservation of freshwater aquatic environments and aquaculture in particular, the Council again noted the potential benefits of aquaculture but provided the following caution "It is very important to recognise, however, that as aquaculture is often based on the utilisation of foreign species of freshwater fish, marron and shrimps, there is always the danger of these becoming established in the wild to the detriment of natural species and the environment. There is also the risk of the introduction of diseases which could be disastrous to native fauna." At the same time it also said that, "The early endeavours in aquaculture were largely concerned with the establishment of trout in the rivers of the Cape, Natal and the Transvaal. By 1920 trout were well established and provided excellent sport, even attracting anglers from overseas. Trout are still a great recreational amenity in Natal and the Transvaal, but the Cape Department of Nature Conservation gradually phased out the breeding and distribution of trout by 1989. Trout were considered a threat to small indigenous fishes, besides which the hatcheries were required for the propagation of indigenous species. Because of the great recreational potential of trout angling, rivers which are suitable for trout should be conserved."

\subsubsection{The Immediate Pre-democracy Status Quo}

Although by 1993 biological invasion legislation had expanded beyond weeds to include alien trees and animals, it still largely followed a 'identify and direct' approach. However, the policy drivers had expanded from purely economic ones 
to include broader natural resource concerns, particularly water, and the environment. Despite this broadening of policy drivers, it is clear from the President's Council Report (The President's Council 1991) that there was a still a policy vacuum in respect of, for example: how considerations of cost and benefit should influence control approaches; how interventions should be prioritised; what control approaches are acceptable; what control strategies should be employed; or whether interventions should be ad hoc or part of a co-ordinated national campaign, programme or strategy.

\subsection{Governance in the Democratic South Africa (1994-Present): Internalising a Rights-Based Culture}

The regulatory initiatives discussed above were undertaken in isolation of the rapid developments in international environmental law that were taking place at the time because of South Africa's ostracism by the international community. With the change in political dispensation, 1994-the year when South Africa elected a democratic government and was reaccepted into the international community in general and the United Nations Environment Programme activities in particularmarked the start of a new wave in the regulation of invasive alien species. There were perhaps two things that provided the impetus for new policy and regulation during this time. These were South Africa's ratification of the 1992 Convention on Biological Diversity in 1995, and the adoption of a new constitutional order in 1996.

With regards to the Convention, when South Africa ratified it on 2 November 1995, it incurred an obligation to domesticate the Convention's requirements, including those in article 8 and subarticle 8(h) which compel South Africa to "as far as possible and as appropriate", "prevent the introduction of, control or eradicate those alien species which threaten ecosystems, habitats or species”. Giving effect to this obligation was not without its challenges because government acknowledged that, "South Africa did not actively participate in the Convention negotiations and has largely been isolated from discussions around its issues. This has resulted in a general lack of awareness and understanding of the complex of issues that it raises." (Department of Environmental Affairs and Tourism 1997).

\subsubsection{The Constitution}

Both the 1993 interim Constitution and the final Constitution (Constitution of the Republic of South Africa 1996) laid the basis for new policy and legislation. This is because in moving to a constitutional democracy, South Africa also moved to a rights-based culture. In this regard, the environmental right which is contained in section 24 of the Bill of Rights says that, "Everyone has the right- 
(a) to an environment that is not harmful to their health or well-being; and

(b) to have the environment protected, for the benefit of present and future generations, through reasonable legislative and other measures that-

(i) prevent pollution and ecological degradation;

(ii) promote conservation; and

(iii) secure ecologically sustainable development and use of natural resources while promoting justifiable economic and social development."

The obligations in paragraph (b) to take reasonable measures to prevent ecological degradation, promote conservation and to secure sustainable development in essence provide a constitutional imperative for government to take action-legislative and otherwise-in respect of invasive alien species in so far as they contribute to degradation or threaten conservation or sustainable development.

\subsubsection{The Draft Biodiversity Policy}

Following the Constitution, government embarked on an extensive environmental policy and law reform process to ensure alignment with the requirements of the Constitution. Although there were many environmental laws that dealt with biodiversity, much of the legislation was outdated in that it tended to focus on managing species diversity and did not reflect the integrated and holistic approach reflected in the Convention on Biological Diversity which recognises that ecosystems, genes, and landscapes need to be managed in addition to species, and that people's interactions with biodiversity must be considered. In addition, existing legislation tended to focus on managing species in protected areas only, rather than across the country as a whole.

The policy process involved establishing an overarching environmental policy which was undertaken through the so-called Consultative National Environmental Policy Process (CONNEPP), as well as a series of sectorally focused policies. One of these sector-based policies was the White Paper on the Conservation and Sustainable Use of South Africa's Biological Diversity (Department of Environmental Affairs and Tourism 1997). The issue of invasive alien species features prominently in several places in the policy. For example, in the discussion on sustainability and the need to minimise negative impacts on biodiversity, the policy notes that, "In aquatic areas, catchment changes, together with alien plant and animal invasions, and domestic, agricultural and industrial pollution, are among some of the primary mechanisms for biodiversity loss." [Emphasis added].

Also important for the purposes of this discussion is Goal 1 of the policy that deals with the conservation of biodiversity. One of the policy objectives for achieving the goal relates directly to alien species. The stated objective is to "prevent the introduction of potentially harmful alien species and control and eradicate alien species which threaten ecosystems, habitats or species". 
In addition, the background discussion on how the policy objective will be achieved contains a number of points that are worth noting. First, as might be expected from an environmental policy, it is clear that the historical economic policy drivers for managing alien species are acknowledged but, for the first time, the main driver of the policy is clearly environmental. This is illustrated by the unambiguous statement that "[t]his policy focuses upon alien organisms which threaten ecosystems, habitats or species". Secondly, the policy makes it clear that government's approach should not entail a form of alien xenophobia because it says that alien species can be categorised as being "(a) those that are problematic and harmful, in that they negatively impact on biodiversity; and $(b)$ those that are benign and in many instances serve useful purposes". Thirdly, the historical emphasis on plants is balanced by an acknowledgement of the impacts of alien animals and marine species. In this regard, the policy notes, for example, that "in the Cape Peninsula ... invasive alien plants are chiefly responsible for the highest concentration of threatened taxa in the world". However, it also notes that, "Introduced animals have also reduced South Africa's biodiversity, a few examples being the Argentinian ant, the Himalayan thar, the European starling, the house sparrow and the black rat, and on South Africa's islands, house mice, rabbits, and feral domestic cats. Some of the most drastic impacts of invasive animal species have been recorded in South African rivers, where alien fish, and to a lesser extent invertebrate and reptile species, have altered habitats and successfully outcompeted native fauna. Up to $60 \%$ of the threatened endemic freshwater fish of South Africa may be threatened by introduced fish species such as trout, carp and bass. Similarly in the marine environment, the accidental introduction of alien species through ballast water or on ship hulls has resulted in a number of alien species occupying our shores and coastal waters, in some instances displacing local species."

Finally, the policy acknowledges that previous policy and legislation had not achieved their objectives, largely due to their ad hoc and reactive nature. The policy therefore proposes a "proactive, preventative and precautionary approach" which "will take into consideration the need to balance the risks associated with introducing and releasing alien organisms with the potential social, economic and environmental benefits derived therefrom". To achieve this, the policy sets out a 13 point action plan which can be summarised as follows-

1. Reforming the law and strengthening compliance and enforcement of the law;

2. Developing legislative requirements for the introduction of alien species that pose a risk;

3. Continuing existing and creating new eradication programmes;

4. Preventing unintentional introductions of species;

5. Developing a policy on the translocation of species within the country;

6. Promoting local, native species in rehabilitation and re-vegetation schemes;

7. Providing incentives to landowners to control or eradicate harmful alien species;

8. Strengthening and coordinating institutional arrangements to identify harmful invasive species proactively and to catalogue invasions;

9. Supporting the development of biological and other control methods; 
10. Improving awareness about the impacts of alien species;

11. Improving education and awareness about the risks posed by the planting or illegal importation of alien species, and identifying actions which can be taken to avoid these risks;

12. Improving capacity amongst the implementing agencies to implement the policy measures; and

13. Negotiating with neighbouring countries to harmonise legislation and practice.

It is noted that despite the policy being published as a White Paper (the usual final formal form of government policy), the White Paper was labelled a "Draft for Discussion" and called for comments to be submitted to the department's Director-General. The document also included a detailed summary of the policy's development process and specifically noted that the only outstanding step in the formalisation of the policy was "the adoption of the White Paper by Parliament as formal policy". Although it is Cabinet, not Parliament, who would usually have approved the White Paper's publication in the Gazette as government policy, the reason why this policy was again published for comment and then apparently abandoned is unclear. There is some speculation that, as this policy was developed through a process that was separate to the highly regarded CONNEPP process, it was abandoned for fear of it being branded as being an illegitimate product of a process that did not fully reflect the democratic ethos and commitment to broad-based participatory policy development espoused by the new democratically elected government at the time. Nevertheless, the White Paper still appears to have provided the policy direction for some aspects of law reform, including the National Environmental Management: Biodiversity Act (Act 10 of 2004) which is discussed below.

\subsubsection{The Biodiversity Act}

The approach of developing both an overarching environmental policy as well as a series of sectorally-focused policies was mirrored in the law reform process that followed. The subsequent promulgation of the National Environmental Management Act (Act 107 of 1998) (NEMA) provided a general framework for managing environmental matters and contained several provisions which may, and in some cases must, be considered when working with other sectorally-focused legislation, including the regulation of invasive alien species. These provisions included a set of environmental principles and definitions as well as an extensive range of compliance and enforcement powers. Whilst NEMA provides an important framework piece of legislation, because of its overarching nature it does not deal with invasive alien species specifically.

The main Act which was passed to supplement NEMA's overarching approach in respect of biodiversity in general is the National Environmental Management: Biodiversity Act (Act 10 of 2004) (Biodiversity Act). Chapter 5 of the Act is dedicated to the regulation of species and organisms that pose potential threats to 
biodiversity and provides the framework for managing alien species and invasive species. It creates an overlapping regulatory regime with that contained in CARA (King et al. 2018). The purpose of the Chapter includes-

- preventing the unauthorised introduction and spread of alien species and invasive species to ecosystems and habitats where they do not naturally occur;

- managing and controlling alien species and invasive species to prevent or minimise harm to the environment and to biodiversity in particular; and

- eradicating alien species and invasive species from ecosystems and habitats where they may harm such ecosystems or habitats.

The Biodiversity Act differentiates between 'alien species' and 'invasive species'. An alien species is one that is not native, or which is native but is found outside its normal distribution range; whereas an invasive species is a species that "(a) threatens ecosystems, habitats or other species or has demonstrable potential to threaten ecosystems, habitats or other species; and (b) may result in economic or environmental harm or harm to human health" (section 1). This distinction caters for the dualistic approach mentioned in Sect. 18.6.4 above and allows government to adopt different approaches to regulating species that pose a risk or threat to the environment and those that do not.

Chapter 5 adopts a four-pronged approach to the management of these species insofar as the public is concerned in a system of permit requirements, prohibitions, exemptions and duties of care. There are strong enforcement mechanisms to secure compliance with these provisions, including administrative enforcement directives which can be issued to compel compliance with the two duties of care and criminal sanctions of up to ZAR 10 million and/or imprisonment of up to 10 years, in addition to any supplementary penalties that can be imposed in terms of NEMA. However, because the Biodiversity Act itself is of a framework nature, it requires further mechanisms such as Regulations and Notices to be passed in order to operationalise and 'give teeth' to the Chapter (cf sections 66, 67, 70 and 97). These are currently found in the Alien and Invasive Species Regulations (GNR 598, GG 37885, 1 August 2014) and the Alien and Invasive Species Lists (GN 599, GG 37885, 1 August 2014, as amended by GN 864, GG 40166, 29 July 2016). The intention of the Regulations is to set out the more detailed rules and procedures that must be followed in respect of alien and invasive species, whereas the Lists (Notices) - as the name impliessets out lists of taxa that are regulated and indicates the form of control that will be applicable to the species. As of the 2016 revised lists, 556 taxa which are considered to be present in South Africa are regulated, and 563 taxa which are considered to be absent from South Africa are prohibited from being imported; see Kumschick et al. (2020), Chap. 20 for more details of how the lists were developed.

The key to understanding the regulatory approach is the concept of 'restricted activities' and its relationship with the Lists. There are 13 restricted activities which relate to alien and invasive species. Five of these are set out in section 1 of the Act and include the importation, possession, growing, breeding, moving or otherwise translocating, selling, buying, donating or in any way acquiring or disposing of a species. The Regulations add a further seven activities: 
(a) spreading or allowing the spread of, any specimen of a listed invasive species;

(b) releasing any specimen of a listed invasive species;

(c) the transfer or release of a specimen of a listed invasive fresh-water species from one discrete catchment system in which it occurs, to another discrete catchment system in which it does not occur; or, from within a part of a discrete catchment system where it does occur to another part where it does not occur as a result of a natural or artificial barrier;

(d) discharging of or disposing into any waterway or the ocean, water from an aquarium, tank or other receptacle that has been used to keep a specimen of an alien species or a listed invasive freshwater species;

(e) catch and release of a specimen of a listed invasive fresh-water fish or listed invasive freshwater invertebrate species;

(f) the introduction of a specimen of an alien or listed invasive species to off-shore islands; or

(g) the release of a specimen of a listed invasive fresh-water fish species, or of a listed invasive fresh water invertebrate species into a discrete catchment system in which it already occurs (regulation 6).

Any person who wants to undertake a restricted activity involving a listed species is generally subject to some form of control. In the case of alien species a permit will be required to undertake the restricted activity (section 65) unless the species has been exempted (section 66 and Listing Notice 2), or the Minister has prohibited the activity in respect of the species completely (section 67 and Listing Notice 4). Invasive species are subject to more stringent forms of control owing to the impact and actual harm that they cause (King et al. 2018). However navigating the requirements in respect of invasive species is more complex because of the way in which the Lists are drafted. In summary, invasive species are categorised in the Lists as falling within category $1 \mathrm{a}, 1 \mathrm{~b}, 2$ or 3 . The reasoning behind the categories can be gleaned from the Regulations (regulations 2-5) which make it clear that the different categories relate to the degree to which the invasive species is considered to be problematic and the corresponding level of control that is considered to be appropriate for managing the problem. Species that are the most problematic-those falling in categories $1 \mathrm{a}$ and $1 \mathrm{~b}$ - are subject to tighter forms of control than those which present the least threat-category 3. In a slight over-simplification, the approach to control in respect of each of the categories is:

- category 1a: the species must immediately be combatted and eradicated by the person in control of the species [this has been interpreted by some to mean a nation-wide eradication attempt is mandated, e.g. Wilson et al. (2013)];

- category $1 \mathrm{~b}$ : the species must be controlled by the person in control of the species;

- category 2: a permit must be obtained to undertake a restricted activity; and

- category 3: these species are either exempt which means that restricted activities can be undertaken without a permit; or they are totally prohibited.

Like the CARA list, the development of categories under the Biodiversity Act creates a conflict between economic and environmental concerns. In this regard, the late Minister of Environmental Affairs, Edna Molewa, said "... the most difficult 
category is the Category 2 species. These are species that have value, such as plantation trees and fish-farming species, and yet can invade with very negative consequences outside of where they are being utilized. The Department has taken an approach that seeks to optimize the economic benefits of these species, whilst minimizing the damage that they cause. Permits are granted for their utilization, but they must be controlled outside of what is allowed in terms of the permit." (www. invasives.co.za).

The regulatory approach which has been described above follows the 'identify and direct' method which is evident in much of the legislation discussed so far. However, the Biodiversity Act and the Regulations have additional nuances which make the regime more progressive than previous laws. The first is that the Act creates a duty of care in respect of alien species and a duty of care in respect of invasive species (sections 69 and 73). In the case of the invasive species duty of care permit holders are required to comply with permit conditions. In addition — and in an expansion of the regulatory net-every landowner who has invasive species on their land is obliged to (a) notify government, (b) take steps to control and eradicate the species and to prevent it from spreading, and (c) take steps to prevent or minimise harm to biodiversity (section 73(2)). The second nuance is that of state responsibility. In this regard, the Act instructs the Minister to "ensure the coordination and implementation of programmes for the prevention, control or eradication of species" and empowers the Minister to establish a body of public servants to co-ordinate and implement these programmes (section 75(4) and (5)). It also requires management authorities of the various protected areas recognised by, or established in terms of, the National Environmental Management: Protected Areas Act (Act 57 of 2003) to include invasive species control and eradication strategies in their management plans and other organs of state to prepare monitoring, control and eradication plans for land under their control (section 76).

In addition to this, the legislation also provides a more coherent basis for evidence-based improvements of the regime by providing for information collection and management and research (Chapters 4 and 5 of the Regulations).

The Biodiversity Act therefore provides a far more comprehensive approach to the management of invasive species, both in the tools that are provided and the range of species that fall within the scope of the Act. There is however room for improvement. In this regard, difficulties in reconciling what is fair to hold individuals accountable and liable for is evident in some of the wording which uses ambiguous terms such as 'appropriate measures' and a poorly defined offences provision in the Regulations. See also Kumschick et al. (2020), Chap. 20 for a discussion on potential improvements to the risk analysis and biosecurity issues.

\subsubsection{Legal Challenges}

Understanding the legal challenges involving legislation can potentially provide useful insights to the policy drivers which are present. Given the relative newness of the Alien \& Invasive Species Regulations and Notices, it is not surprising that 
there has been limited litigation involving them. But as with much of the litigation involving biodiversity, the underlying drivers for the litigation can be a clash of cultural ethics, self-interest (economic) or a desire to protect the environment.

One case, Kloof Conservancy v Government of the Republic of South Africa and Others (D) Case No: 12667/2012, 22 October 2014, was aimed at forcing government to give effect to its regulatory obligations. In this regard, in terms of section 70 (1)(a) of the Biodiversity Act, the Minister was obliged to publish the national list of invasive species within 2 years of the section coming into effect. In December 2012 - more than 6 years after the deadline for publishing the list-the Kloof Conservancy applied to court for an order compelling the Minister to publish the list as well as the Regulations. Before the matter reached trial the Minister published interim 2013 Regulations and Notices, presumably in an effort to defeat the application. The Kloof Conservancy, however, launched a second application asking for the 2013 Regulations and Notices to be reviewed and set aside as well other orders to be made. Between arguing the case and the judgment being made, the Minister passed the 2014 Regulations and 2014 Notice. This meant that much of the Kloof Conservancy's requests became moot because the Regulations and Notice had been passed.

Notwithstanding this, the court showed its displeasure with the almost 8-year delay in passing the Regulations and Notice by awarding costs against government on an attorney-and-client basis i.e. a punitive costs order. It also declared the failure to publish the Regulations and Lists timeously to be unconstitutional and unlawful. In an unusual approach the court also made orders about implementation. It ordered that all steps had to be taken to ensure that organs of state complied with their duties and directed the Minister to appoint enough environmental management inspectors to ensure compliance with government's duties in relation to invasive alien species in Kwa-Zulu Natal within 6 months of the judgment (Note: the Minister successfully appealed aspects of the judgment related to the deployment of environmental management inspectors-See Minster of Water and Environmental Affairs $v$ Kloof Conservancy (106/2015) [2015] ZASCA 177 (27 November 2015).

Although not directly related to his findings, the judge also expressed some reservations about the 'legality' of aspects of the 2014 Regulations. These obiter dictum comments may encourage future litigation on the Regulations.

By contrast to the Kloof matter, another case was initiated in the early 2000's (before the Alien and Invasive Species Regulations were promulgated) with the aim of preventing government from exercising its powers. This case related to the sentimental and ethical considerations that can arise in the context of alien species, particular animal species. In this instance government took a policy decision to extirpate the Himalayan Tahr (Hemitragus jemlahicus) on Table Mountain, whose ancestors had been introduced to South Africa from India by Cecil John Rhodes. The decision was met with outrage by many people, some of whom formed the "Friends of the Tahr" group, to challenge the culling. "Friends of the Tahr" launched an application to have the decision to cull reviewed. It was either withdrawn or dismissed (Butcher 2004). The matter may be resurrected in the future as a media article reports that the group was looking to approach the court about the possible culling of three remaining tahrs which were sighted in 2017 (Chambers 2017). 
A third case shows how alien species regulation can be used in private disputes. Appelgryn N.O. and Another v Jankielsohn and Others ((FS) Case No. 3809/2016), 19 January 2017 involved a dispute about the ownership of a number of Red Lechwe Antelope. In this instance, the court found that because the antelope are alien species which are regulated in terms of the Biodiversity Act, the neighbour's keeping or allowing the antelope to be on her land was a restricted activity which required a permit. In the absence of a permit, it held that she was acting illegally and therefore had no right (locus standi) to defend the application.

\subsubsection{The "Working for" Programmes: The Only Coherent National Programme for Managing Invasive Species?}

The discussion on the legislation in previous sections has indicated that, apart from imposing obligations on the public, a co-ordinated government response is required to manage invasive species. In 1995, drawing heavily on hydrological and ecological insights from tree invasions in the Cape, the Working for Water (WfW) Programme became the first coherent national programme for managing invasive species. The 1997 White Paper on the Conservation and Sustainable Use of South Africa's Biological Diversity (Department of Environmental Affairs and Tourism 1997) recognised the fledgling WfW Programme as "an RDP (Reconstruction and Development Programme) project ... to clear invasive alien vegetation as part of a water conservation campaign and job-creation scheme" and included providing “.. .ongoing support to existing programmes. .." as a component of 1 of its 13 interventions aimed at "preventing the introduction of potentially harmful alien species and controlling and eradicating alien species which threaten ecosystems, habitats or species" (the RDP was the South African government's first socio-economic policy framework following democracy in 1994). With this, given that another of the draft policy's interventions was to "improve capacity amongst implementing agencies to regulate the introduction, control and eradication of alien organisms that threaten biodiversity", it seems clear that the "water conservation and job-creation RDP project' was never envisaged as being the only 'coherent national programme for managing invasive species'.

According to van Wilgen and Wannenburg (2016), in establishing WfW, the Minister of Water Affairs and Forestry insisted that its projects should be implemented at a national scale as "the need to create employment was ubiquitous" and the problem of invasive species was not only confined to the area receiving the most attention, namely the Cape Floristic Region. This nation-wide approach was seen as making both political and ecological sense. Since its establishment, WfW has been expanded into more "Working for" programmes including inter alia Working for Wetlands, Working for Land and Working on Fire, dealing with wetland and degraded land rehabilitation and wildfire management respectively.

From a policy perspective, it is important to note the change in emphasis between this 'job-provision/ invasion problem' prioritisation balance of WfW and the 
abandoned draft policy's third intervention which reads, "Develop control and eradication programmes, and provide ongoing support to existing programmes, based on a priority-rating system and in relation to costs and resources. This will consider threats posed to biodiversity, as well as social, economic, and environmental costs and benefits derived from using and removing identified organisms. The planning of intensive mechanical clearing operations will take account of job creation schemes and will provide for regular follow-up." [Emphasis added].

Van Wilgen and Wannenburg (2016) note that WfW projects are often selected to meet one or the other goal, "resulting in confusion about how to prioritise projects" and that the compromises inherent to the 'job-provision/invasion problem' prioritisation balance often result in projects that are not optimally selected.

Furthermore, there are also other challenges associated with the "Working for" programmes being the only coherent national programmes for managing invasive species, not least of which is the concern that local management capacity may be being undermined. According to van Wilgen et al. (2016), funds may be being diverted from organisations that have been established with the express goal of promoting the collective management of resources locally (for example, conservancies, Fire Protection Associations and Catchment Management Agencies) and conservation management agencies (for example, CapeNature and South African National Parks) to the detriment of such organisations. These agencies are then unable to build and maintain the necessary local capacity to efficiently and effectively manage the problem which, according to van Wilgen et al. (2016), essentially renders these organisations bystanders to the "Working for" programmes.

Despite its shortfalls, WfW is broadly considered, both nationally and internationally, to be a resounding success. However, the "Working for" programmes have effectively become the only significant national biological invasion response programme. From a purely biological invasion policy perspective this is not optimal-rather than being the only programme, the "Working for" programmes should be unashamedly job-provision focussed key components of a broader national programme that is unambiguously focussed on efficient and effective biological invasion management as envisaged by the abandoned policy.

\subsection{Discussion and Future Directions}

The recent report on the status of biological invasions and their management in South Africa in 2017 (van Wilgen and Wilson 2018) contains a number of "policyrelevant messages". It makes it clear that although there is a long legislative history of interventions aimed at controlling biological invasions, the number of problem species, the extent of invasion and magnitude of negative impacts is still growing. Although the report does provide a critique of the 2014 Alien \& Invasive Regulations and Lists, it does not specifically refer to policy or legislative failures as being a root cause for the apparent lack of overall success in dealing with biological invasions. However, the report does make it clear that "the lack of adequate planning 
and monitoring of the outcomes of control measures has been identified as a major weakness in South Africa" (van Wilgen and Wilson 2018).

Bennett and van Sittert's recent historical review (2018) also concludes that "the history of invasive alien plant and weed management has been chequered in its environmental and social outcomes." They believe governance efforts have faltered because of the difficulty of engaging private land owners, competition, local viewpoints and limited support for technical interventions by scientists and managers. Furthermore, differing perceptions of invasive species have meant that "some regions are better endowed with facilities and awareness than others to tackle the complex challenges associated with invasion" (Bennett and van Sittert 2018). Although invasive species, especially trees, are widely recognised as a national problem by scientists and growing public numbers, there is no broad consensus on what species cause the most problems.

As discussed below, it is possible that the lack of a dedicated biological invasion policy lies at the heart of van Wilgen and Wilson's concerns around inadequate planning and monitoring as well as the issues highlighted by Bennett and van Sittert (2018) that are bedevilling good governance and efficient and effective biological invasion management.

\subsubsection{The Policy Vacuum}

Despite over 160 years of concern around biological invasions, South Africa still has no formal national policy on the issue. Without formal policy there is no accepted government position on questions like-

- What is the overall vision for biological invasion management in South Africa?

- How do South Africans decide which are 'acceptable' and 'unacceptable' invasive species and under what circumstances?

- What would South Africans regard as 'acceptable change' to the land or landscape brought about by biological invasions and under what circumstances?

- Should some highly-invaded landscapes be 'sacrificed' to the invading species and under what circumstances?

- How should the invasive species legacy be dealt with?

- How should South Africa prioritise biological invasion management interventions?

- How, and how often, should South Africa review biological invasion management strategies and priorities?

- What types of biological invasion management interventions are accepted, not accepted or preferred, and under what circumstances?

- Who should implement biological invasion management interventions and under what circumstances?

- How will we measure the success, or otherwise, of biological invasion management interventions? 
- How should biological invasion management interventions be co-ordinated, if at all?

- Who should pay for biological invasion management interventions and under what circumstances?

- How should South Africa build, maintain and retain efficient and effective biological invasion management capacity?

Although the draft White Paper on the Conservation and Sustainable Use of South Africa's Biological Diversity started to provide some initial guidance in this regard, its status as a draft rather than final policy has ensured that it has largely descended into obscurity and, as a result, it is not referenced at all in important policy-dependant or policy-relevant publications like the 2014 draft National Strategy for dealing with Biological Invasions in South Africa (Department of Environmental Affairs 2014) or the report on the status of biological invasions and their management in South Africa in 2017 (van Wilgen and Wilson 2018).

Without guidance on the important questions listed above, it is possible that biological invasion-related legislation is not tailored to achieve a specific desired and strategic outcome, but largely continues to follow the historical 'identify and direct' approach. Without nationally accepted guidance on desired outcomes and indicators for their measurement (cf. Wilson et al. 2018), all biological invasion management strategies and plans are likely to be no more than lists of activities and good intentions. Without guidance on prioritisation, valuable and limited resources may not be being used optimally. Without guidance on what interventions are preferred it is possible that some interventions may be resulting in perverse outcomes.

It is also probably safe to conclude that the over 6-year delay in the publication of the Regulations and Notices referred to in Sect. 18.7.4 above was probably exacerbated by the lack of policy, i.e. the 6-year development process would have been greatly reduced if the development of the Regulations and Notices were directed by clear and unambiguous national policy.

Finally, without policy, the dubious 'nationalistic' or 'species xenophobia' justification for invasive alien species eradication remains unchallenged. For example, Pooley (2010) suggests that the very existence of WfW "is founded on antagonism to harmful introduced species, and advocates routinely use emotive language referring to 'cleaning' areas of 'infestations' of 'alien' plants, which 'threaten to engulf and exterminate the unique indigenous fauna and flora". Alarmingly, Pooley (2010) notes that parallels have been drawn between the focus on invasive alien plants in the emotional public response to the devastating veld fires in the Western Cape of 2000 and xenophobia in contemporary South Africa.

\subsubsection{Law, Compliance and Enforcement}

The first biological invasion-related 'action point' of the draft White Paper on the Conservation and Sustainable Use of South Africa's Biological Diversity is that the law required reforming and that strengthened compliance and enforcement of the 
law was needed. With regard to the latter point, there is a general rule of thumb for legal compliance that goes-for a just law, $10 \%$ of the regulated community will always comply, $10 \%$ will never comply and the remaining $80 \%$ will comply if they believe that the non-compliant $10 \%$ will be brought to book. What this means is that if the regulated community broadly believes that there is a relatively high likelihood that they will be caught and punished if they break the law, then the vast majority of the community will comply. However, if the regulated community broadly believes that there is a relatively low chance that they will be caught and punished then the vast majority of the community will not comply. Although this rule of thumb may be an oversimplification of deterrence and compliance promotion, which is a complicated and not well-understood area that also involves, among others, awareness of the law and ability to comply, it is used here for the sake of argument.

In the current context, the 'regulated community' comprises of all South African land owners and users, and it is probably fair to say that, of the regulated community that actually know their invasive species management legal obligations, very few are likely to believe that they will be caught and punished for non-compliance. Hence, it is highly likely that the level of non-compliance with invasive species law in South Africa is extremely high and, as a result, invasive species legislation is unlikely to be having the desired effect or impact. With this, it could also be argued that very little has changed in the legislative approach since the 1874 Burr Weed Law that noted that "the Law hitherto in force has failed to check the spread" of the weed. Thus it appears that enforcement may be an extremely important issue when dealing with invasive policy and legislation.

With reference to the compliance rule of thumb above, this 'rule' only holds true if the law is regarded as a 'just law'-law that is fair and reasonable. In a Constitutional democracy like South Africa, 'unjust law' can be prone to legal and popular challenge, making it difficult or impossible to enforce. Given that the majority of the regulated community are seldom directly or knowingly responsible for introducing an invasive species onto their land, it is easily argued that they are, in fact, the 'victims' of invasive species (Fig. 18.3). Indeed, it would probably be considered grossly unfair and unreasonable to hold a landowner responsible for polluted ambient air over her land if the pollution is from, say, a neighbouring factory. Thus, there could be a case to be made that government may be loath to enforce 'faultless liability' where the 'culprit' may, in fact, be the 'victim' of poor invasive species management by others.

Furthermore, perhaps the 'environmental justice principle' contained in NEMA also provides a useful test of whether South African biological invasion-related law is, in fact, 'just law'. Section 2(4)(c) of NEMA requires that "[e]nvironmental justice must be pursued so that adverse environmental impacts shall not be distributed in such a manner as to unfairly discriminate against any person, particularly vulnerable and disadvantaged persons." With this it may be possible that the few people who have knowingly or purposefully introduced invasive species are distributing the adverse environmental impacts of these species to others, including vulnerable and disadvantaged persons. Despite this, the law requires these 'innocent' people to address these adverse environmental impacts. 


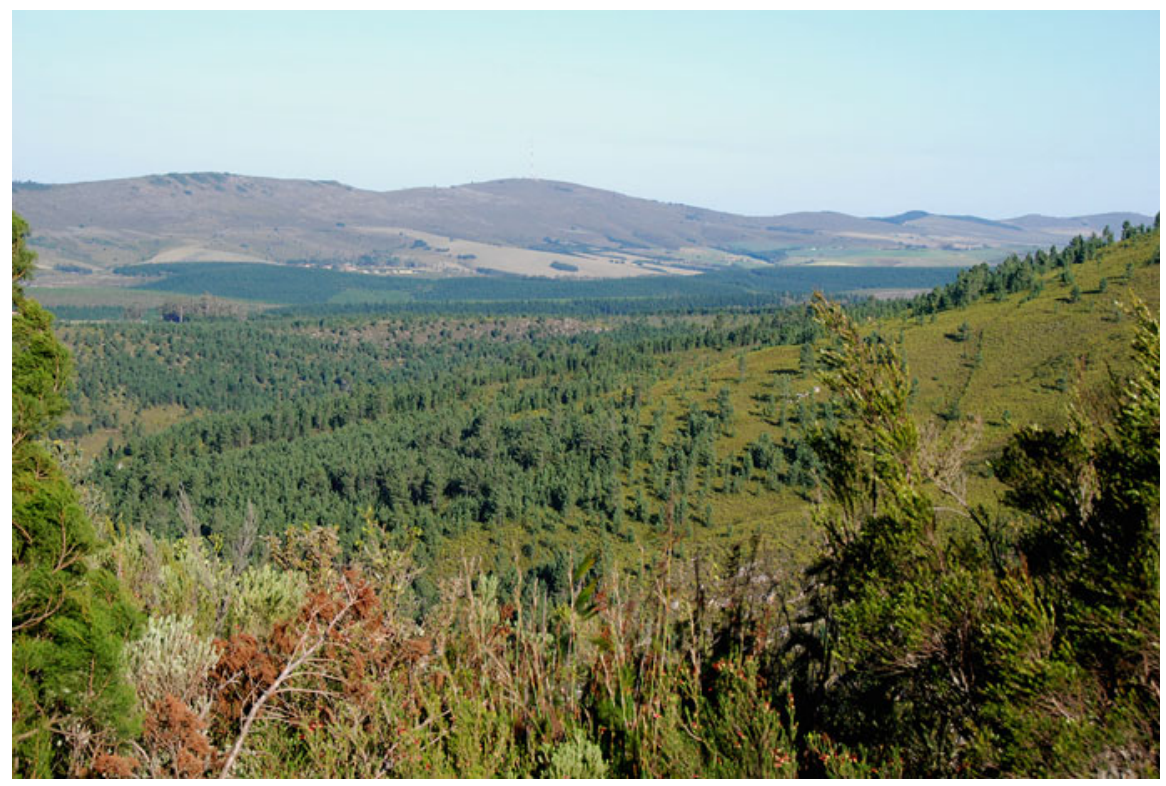

Fig. 18.3 Garcia Pass, Western Cape-Pine trees invading Cape Nature land in the foreground with the commercial forest source of the pines in the background. Photograph courtesy of Brian W. van Wilgen

Other than justice considerations, enforceability, capacity and political will all impact on the effectiveness of enforcement, where enforceability refers to the extent to which a law may be efficiently and effectively enforced using available resources; capacity refers to structures, financial and technical resources, systems, strategies, skills, incentives and networks required for efficient and effective enforcement; and political will refers to the motivation, willingness, enthusiasm and political support for efficient and effective enforcement.

Although a full analysis of these considerations is beyond the scope of this Chapter, it is likely that all of the above factors have an impact on how useful the current legal regime is in managing biological invasions.

This notwithstanding, and despite the apparent challenges associated with the 'identify and direct' approach to biological invasion law that were recognised as far back as 1874 , this approach still appears to be the core of our legislation.

\subsubsection{The Future}

It seems clear from the recent report on the status of biological invasions in South Africa (van Wilgen and Wilson 2018) that, despite relatively large public investments in dealing with the biological invasion problem, we appear to be losing 
the battle (cf. Wilson et al. 2020, Chap. 31). Furthermore, the report also makes it clear that the battle is becoming harder as the number of species causing major impacts and the magnitude of the impacts themselves grow, as further species become invasive, and as others enter a phase of exponential spread. Furthermore, according to Hellmann et al. (2008) and King et al. (2018), it will take more research to understand how specific invasive species may behave under an altered climate and which species will become invasive in the future.

With this, it seems that the current policy vacuum must be addressed as a matter of urgency in order to establish a national consensus on how we as South Africans view biological invasions, what our desired future looks like in terms of biological invasions, and how we intend to realise that desired future. As biological invasions affect all South Africans, this policy development process must be evidencebased and should follow the co-creation approach described by von der Heyden et al. (2016). In this regard, not only should the policy deal with the questions listed in Sect. 18.8.1 above, it should also deal with issues like the commercial exploitation of alien species, and how NEMA's polluter-pays principle may be applied in cases where such exploitation results in invasion of neighbouring land and rivers. Furthermore, a good-practise participatory policy development process is an excellent way of ventilating and addressing Bennett and van Sittert's (2018) issues of private land owner concerns and interests, faultless liability, conflicting interests and competition, local viewpoints, support for technical interventions by scientists and managers, differing perceptions of invasive species and the means of identifying and prioritising what species cause the most problems.

Perhaps growing concerns around climate change and interest in the global Sustainable Development Goals may provide the perfect 'policy-development window' for the development of formal policy on biological invasion in South Africa.

Acknowledgements We acknowledge the clear direction and support from Professor Brian van Wilgen of the Centre for Invasion Biology, Stellenbosch University, and Ms Marié Theron, Faculty Librarian: Science, Library and Information Service, Stellenbosch University for the links to the invaluable historical legislation databases. We would also like to thank SANBI's Sebataolo Rahlao for his comments and suggestions, as well as those of the peer reviewers.

\section{Electronic Supplementary Material}

A data-set containing all promulgated legislation relevant to biological invasions in South Africa, compiled as part of this project, is available on https://zenodo.org/ record/3660175\#.Xj-zbTEzaUk 


\section{References}

Barton GA (2002) Empire forestry and the origins of environmentalism. University of Cambridge Press, Cambridge. https://doi.org/10.1017/CBO9780511493621

Beinart W (2003) The rise of conservation in South Africa: settlers, livestock, and the environment 1770-1950. Oxford University Press, Oxford

Bennett BM (2010) The El Dorado of forestry: the Eucalyptus in India, South Africa, and Thailand, 1850-2000. Int Rev Soc Hist Suppl 55:27-50. https://doi.org/10.1017/S0020859010000489

Bennett BM (2014) Model invasions and the development of national concerns over invasive introduced trees: insights from South African history. Biol Invasions 16:499-512. https://doi. org/10.1007/s10530-013-0601-1

Bennett BM, van Sittert L (2018) Historicising perceptions and the national management framework for invasive alien. J Environ Manage 229:174-181. https://doi.org/10.1016/j.jenvman. 2018.07.029

Britton N, Brown A (1913) An illustrated flora of the Northern United States, Canada and the British possessions, 2nd edn. Charles Scribner's Sons, New York. https://doi.org/10.5962/bhl. title. 55504

Butcher T (2004) Anger as shaggy 'aliens' of Table Mountain face mass slaughter. The Telegraph, 22 May

Cape of Good Hope Parliament (1871) Statutes of the Cape of Good Hope, passed by the Second Parliament, during the sessions 1859-1863. Saul Solomon \& Co., Cape Town

Carruthers J (2011) Trouble in the garden: South African botanical politics ca. 1870-1950. S Afr J Bot 77:258-267. https://doi.org/10.1016/j.sajb.2011.02.005

Chambers D (2017) Alive and on a high: three tahrs pictured on Table Mountain. Times Live, 13 July 2017

Crosby AW (1986) Ecological imperialism: the biological expansion of Europe, 900-1900. Cambridge University Press, Cambridge

Department of Environmental Affairs (2014) A national strategy for dealing with biological invasions in South Africa, Draft dated 25 March 2014. Department of Environmental Affairs, Pretoria

Department of Environmental Affairs and Tourism (1997) White Paper on the Conservation and Sustainable Use of South Africa's Biological Diversity, May 1997, Draft for discussion (Notice No. 1095 of 1997, Government Gazette No. 18163 of 28 July 1997). Government Printer, Pretoria

DPME, UCT (2014) Overview Paper: What is evidence-based policy-making and implementation? Department of Planning Monitoring and Evaluation. October. http://www.dpme.gov.za/ keyfocusareas/evaluationsSite/Evaluations/What\%20is\%20EBPM\%2014\%2010\%2013_mp. pdf. Accessed 23 July 2018

Education and Training Unit (n.d.) The policy and law making process. Education and Training Unit for Democracy and Development (ETU). http://www.etu.org.za/toolbox/docs/govern/pol icy.html. Accessed 5 June 2018

Grove R (1989) Scottish missionaries, evangelical discourses and the origins of conservation thinking in southern Africa 1820-1900. J S Afr Stud 15:163-187. https://doi.org/10.1080/ 03057078908708196

Hanks K (2001) A legal solution? The Conservation of Agricultural Resources Act explained. Department of Water Affairs and Forestry. www.dwaf.gov.za/wfw/Docs/Articles/CARA.doc. Accessed 22 Aug 2018

Hellmann JJ, Byers JE, Bierwagen BG, Dukes JS (2008) Five potential consequences of climate change for invasive species. Conserv Biol 22:534-543. https://doi.org/10.1111/j.1523-1739. 2008.00951.x

Invasive Species South Africa (n.d.) Spiny cocklebur. http://www.invasives.org.za/legislation/item/ 314-spiny-cockleburxanthium-spinosum. Accessed 24 July 2018 
King ND, Strydom HA, Retief FP (2018) Environmental management in South Africa, 3rd edn. Juta, Cape Town

Kruger FJ, Bennett BM (2013) Wood and water: an historical assessment of South Africa's past and present forestry policies as they relate to water conservation. Trans Roy Soc S Afr 68:163-174. https://doi.org/10.1080/0035919X.2013.833144

Kumschick S, Foxcroft LC, Wilson JR (2020) Analysing the risks posed by biological invasions to South Africa. In: van Wilgen BW, Measey J, Richardson DM, Wilson JR, Zengeya TA (eds) Biological invasions in South Africa. Springer, Berlin, pp 569-592. https://doi.org/10.1007/ 978-3-030-32394-3_20

Malherbe HL (1968) Report of the Interdepartmental Committee of investigation into afforestation and water supplies in South Africa. Government Printer, Pretoria

Marais L, Matebesi Z (2013) Evidence-based policy development in South Africa: the case of provincial growth and development strategies. Urb For 24:357-371. https://doi.org/10.1007/ s12132-012-9179-4

Peretti JH (2010) Nativism and nature: rethinking biological nativism. In: Johnson S (ed) Bio-invaders. White Horse Press, Winwick, Cambridgeshire, pp 28-36

Pooley S (2010) Pressed flowers: notions of indigenous and alien vegetation in South Africa's Western Cape, c. 1902-1945. J S Afr Stud 36:599-618. https://doi.org/10.1080/03057070. 2010.507565

Republic of South Africa (1996) Constitution of the Republic of South Africa (Act No. 108 of 1996). Pretoria, Government Printer

Strydom WF, Funke N, Nienaber S et al (2010) Evidence-based policymaking: a review. S Afr J Sci 106(5/6), 8 pp. https://doi.org/10.4102/sajs.v106i5/6.249

The President's Council (1991) Report of the Three Committees of the President's Council on a National Environmental Management System. Government Printer, Pretoria

van Sittert L (2000) 'The seed blows about in every breeze': noxious weed eradication in the Cape Colony, 1860-1909. J S Afr Stud 26:655-674. https://doi.org/10.1080/713683604

van Sittert L (2003) Making the Cape floral kingdom: the discovery and defence of indigenous flora at the Cape ca. 1890-1939. Landscape Res 28(28):113-129. https://doi.org/10.1080/ 01426390306529

van Wilgen BW (2020) A brief, selective history of researchers and research initiatives related to biological invasions in South Africa. In: van Wilgen BW, Measey J, Richardson DM, Wilson JR, Zengeya TA (eds) Biological invasions in South Africa. Springer, Berlin, pp 31-64. https:// doi.org/10.1007/978-3-030-32394-3_2

van Wilgen BW, Wannenburgh A (2016) Co-facilitating invasive species control, water conservation and poverty relief: achievements and challenges in South Africa's Working for Water programme. Curr Opin Environ Sustain 19:7-17. https://doi.org/10.1016/j.cosust.2015.08.012 van Wilgen BW, Wilson JR (2018) The status of biological invasions and their management in South Africa in 2017. South African National Biodiversity Institute, Kirstenbosch and DST-NRF Centre of Excellence for Invasion Biology, Stellenbosch

van Wilgen BW, Carruthers J, Cowling RM et al (2016) Ecological research and conservation management in the Cape Floristic Region between 1945 and 2015: history, current understanding and future challenges. Trans Roy Soc S Afr 71:207-303. https://doi.org/10.1080/0035919X. 2016.1225607

von der Heyden S, Lukey P, Celliers L et al (2016) Science to policy - reflections on the South African reality. S Afr J Sci 112:1-6. https://doi.org/10.17159/sajs.2016/a0183

Weyl OLF, Ellender B, Wassermann RJ et al (2020) Alien freshwater fauna in South Africa. In: van Wilgen BW, Measey J, Richardson DM, Wilson JR, Zengeya TA (eds) Biological invasions in South Africa. Springer, Berlin, pp 151-182. https://doi.org/10.1007/978-3-030-32394-3_6

Wilson JRU, Ivey P, Manyama P et al (2013) A new national unit for invasive species detection, assessment and eradication planning. S Afr J Sci 109: Art. \#0111, 0113 pp. https://doi.org/10. 1590/sajs.2013/20120111 
Wilson JRU, Faulkner KT, Rahlao SJ et al (2018) Indicators for monitoring biological invasions at a national level. J Appl Ecol 55:2612-2620. https://doi.org/10.1111/1365-2664.13251

Wilson JR, Foxcroft LC, Geerts S et al (2020) The role of environmental factors in promoting and limiting biological invasions in South Africa. In: van Wilgen BW, Measey J, Richardson DM, Wilson JR, Zengeya TA (eds) Biological invasions in South Africa. Springer, Berlin, pp 353-384. https://doi.org/10.1007/978-3-030-32394-3_13

Open Access This chapter is licensed under the terms of the Creative Commons Attribution 4.0 International License (http://creativecommons.org/licenses/by/4.0/), which permits use, sharing, adaptation, distribution and reproduction in any medium or format, as long as you give appropriate credit to the original author(s) and the source, provide a link to the Creative Commons licence and indicate if changes were made.

The images or other third party material in this chapter are included in the chapter's Creative Commons licence, unless indicated otherwise in a credit line to the material. If material is not included in the chapter's Creative Commons licence and your intended use is not permitted by statutory regulation or exceeds the permitted use, you will need to obtain permission directly from the copyright holder. 